ORIGINAL ARTICLE

\title{
Examination of University Students' Nomophobia, Coping with Stress, and Anger Expression Styles
}

\author{
ALI OSMAN KIVRAK \\ Selçuk University, Faculty of Sports Science, Konya, Turkey \\ Correspondence to Ali Osman Kıvrak, Email. aokivrak@selcuk.edu.tr, Cell: 05057382670
}

\begin{abstract}
Aim: With this study, it is aimed to examine the nomophobia, coping with stress and anger expression styles of university students.

Methods: A total of 532 university students $(n=201$ female; $n=331$ male) participated in the study. While the personal information form created by the researcher was used for socio-demographic data, the nomophobia scale developed by Yıldırım and Correia (2015) and adapted into Turkish by Yıldırım et al. (2016) for smartphone addiction, Anger Expression Style Scale, developed by Spielberger et al. (1983) and adapted to Turkish by Özer (1994), was used to determine anger expression styles, and the "Stress Coping Style Scale", which was developed by Folkman and Lazarus (1980) and adapted into Turkish by Şahin and Durak (1995), was used to determine stress coping styles. The homogeneity and variances of the data were tested, Independent Samples $t$ Test was used for pairwise comparisons, One Way Anova was used for multiple comparisons, and Tukey HSD test was used to determine the source of difference.

Results: While no statistical change was observed in the dimensions of coping with anger and stress depending on the gender factor, it was determined that the mean value of males was statistically higher than that of females in all nomophobia dimensions $(p<0.05)$. There was no statistical change in the values of anger, nomophobia and coping with stress depending on the age and accommodation factors of the students.

Conclusion: Today, the fact that female and male are closer to each other in respect of social status and social roles can be seen as the reason for the similarity in the values of anger expression and coping with stress. Results related to high nomophobia of males values can be evaluated as they are more addicted to smartphones than females.
\end{abstract}

Keywords: Nomophobia, University Student, Stress, Anger

\section{INTRODUCTION}

WHO (2020) defines 10-19 years of age as adolescents, 15-24 years of age as youth, and 10-24 years of age as young people ${ }^{1}$. University students also contain a nonspecific structure that is included in the stereotypes of adolescents, youth, and young people, but also includes adult people. University students have to struggle with many different problems besides the problems related to education. In addition to getting used to a new environment, they are expected to cope with many different socio-cultural situations as well as problems such as accommodation and nutrition. Bayram and Bilgel ${ }^{2}$ suggest that being a university student forms the basis of an environment that will generate anxiety and stress in our country or in other countries. Çam Çelikel and Erkorkmaz ${ }^{3}$ reported that young people may experience psychological problems while solving their issues. Undoubtedly, the most important negative behaviors are emotions and expressions such as stress, anger and aggression. Anger is a normal emotion that is experienced frequently, exists in different processes and intensities, from minor disappointments to intense anger, accompanied by physiological and biological changes ${ }^{4}$. Anger occurs as a secondary emotion due to the effect of many internal and external factors. The most usable and positive form of anger is undoubtedly its controllable level. Anger can be defined as one of the natural, basic emotions in the individual ${ }^{5}$.

The concept of anger, which is considered as a natural affect, should be controlled before it takes on a structure that will suppress the positive behaviors of young people. Greenberg ${ }^{6}$ defines stress as the mental, emotional, and physical reactions of the human body against the environmental tensions and pressures that arise by pushing the limits of the organism. It takes place as an obstacle in front of positive emotions and behaviors, pushing the mental and physical limits of young people, making them unable to do what they can do. It is possible to ensure that stress, like anger, serves the organism as a controllable emotion. Another factor that causes these negative emotions and behaviors to increase is the devices that cause digital addiction such as tablets, laptop computers and smart phones, which are called innovations brought by technology. The biggest threat for young people today is digital addictions, which have become one of today's problems with technological developments. The main one of these addictions is nomophobia. Yıldırım and Correia $^{7}$ define nomophobia as the unreal anxiety that a person feels when she/he cannot reach or communicate using his mobile device; King et al. ${ }^{8}$ define it as a technological disease that arises from the lack of smart devices such as tablets, mobile phones, computers with which virtual communication is made, and that occurs with the state of anxiety and restlessness. Kuss and Griffiths ${ }^{9}$ report that unnecessary and long-term use of devices such as computers, tablets and smartphones can cause psychiatric disorders, decreased academic performance, and deterioration of social and emotional relationships.

Bragazzi and Del Puente ${ }^{10}$ describe nomophobia symptoms as spending a lot of time with a smart phone, checking it frequently, sleeping with it without being 
turned off, communicating only with it, spending too much time on the smart phone, and staying away from places where smart phone use is not allowed. It is possible to come across publications stating that individuals prefer smartphones for reasons such as being able to connect to the internet, being programs that can be easily installed and uninstalled, being easily portable, being a tool for electronic transactions, shopping, audio-video calling, using, and sharing on social media ${ }^{11,12,13}$.

Nomophobia should be dealt as an addiction with a structure that can cause many mental disorders. It is possible to come across studies in the literature that digital addictions cause many mental and physical health problems $9,14,15,16,17$. Lee et al. ${ }^{18}$ also emphasized that the first users of smartphones were university students. In order to adapt to a new environment and to keep up with the socio-cultural structure, university youth meet many problems with smart phones, which are a very easy way to connect with their relatives. Bragazzi et al. ${ }^{10}$ report that digital addictions can cause social and physical disorders in individuals and harm social relations.

Although there are many studies on the problems of university students, it is seen that studies on the physical and mental damage caused by nomophobia and digital addictions in individuals are quite limited. In this respect, the research is important in terms of keeping university students away from negative emotions and behaviors.

\section{MATERIAL \& METHODS}

With this study, it is aimed to examine the nomophobia, coping with stress and anger expression styles of university students. A total of 532 university students, 201 females and 331 males, participated in the study. For this study, an ethics committee report was obtained from the noninterventional clinical research ethics committee of Selçuk University, Faculty of Sport Sciences, with the decision dated 20.05.2021 and numbered 79 .

Data Collection Tools: While the personal information form created by the researcher was used for sociodemographic data, Nomophobia scale developed by Yıldırım and Correia ${ }^{7}$ was used for smartphone addiction, The Anger Expression Style scale developed by Spielberger et al. ${ }^{19}$ and its Turkish adaptation made by Özer 20 was used to determine anger expression styles, The Stress Coping Style Scale, which was developed by Folkman and Lazarus 21 and adapted into Turkish a short form developed by Şahin and Durak 22 was used in the determination of Coping Styles with Stress. Individuals with a smart phone, a GSM line connected to the internet and a fixed internet connection at home were included in the study.

Nomophobia Scale: The scale, consisting of a total of 20 items, was developed by Yıldırım and Correia ${ }^{7}$. The scale, which was adapted into Turkish by Yıldırım et al. ${ }^{23}$, has 20 items and four sub-dimensions, as in the original form. In the study; the updated version of the scale a 5-point likert type by Erdem et al. ${ }^{24}$ was used.

The scale, which has four sub-dimensions, consists of "Unable to Access Information "dimension (m1-m4) 4 items, "Losing Online Connection" dimension (m5-m9) consists of 5 items, "Unable to Communicate "dimension (m10-m15) consists of 6 items and "Renunciation of Comfort "dimension (m16- m20) consists of 5 items.

The Style of Coping with Stress Scale: In The Style of Coping with Stress Scale, which was developed by Folkman and Lazarus ${ }^{21}$ and adapted Turkish, and a short form was created by Şahin and Durak 22 is consisting of 30 items and in this scale which is scored between 0 and 3 , the 1st and 9th items are calculated by reverse scoring in the calculation of applying for social support. Scores for each factor are calculated separately. The scores obtained from the questions belonging to each factor are summed and divided by the total number of questions belonging to that factor to obtain the average score for each factor. The lowest score that can be obtained from each subscale is 0 , and the highest score is 3 . The total score is not calculated. As the scores obtained from the self-confident, optimistic and seeking social support factors increase, it indicates that coping with stress is effective, and the increase in the scores obtained from the helpless, submissive approach factors indicates that ineffective methods are used in coping with stress.

Trait Anger and Anger Expression Style Scale: The scale developed by Spielberger et al. ${ }^{19}$ was adapted into Turkish by Özer 20 . The scale is a 4-point Likert-type scale with 34 items. Not at all (1 point), Some (2 points), Quite (3 points), and Totally (4 points). The first 10 items of the scale measure trait anger, and the next 24 items measure anger expression styles. Trait anger expresses how the person generally feels and how much anger he or she experiences. The lowest score that can be obtained from the Trait Anger scale is 10, and the highest score is 40. Anger Expression Style Scale, anger inward (items 13, 15, 16, 20, 23, 26, 27, and 31), anger outward (items 12, 17, 19, 22, 24, 29, 32, and 33) and anger control (items 11, 14, 18, 21, 25, 28, 30 and 34).

Statistical Analysis: SPSS 22.0 IBM statistical program was used for the evaluation of the data obtained. The homogeneity and variances of the data were tested, Independent Samples t Test was used for pairwise comparisons, One Way Anova was used for multiple comparisons, and Tukey HSD test was used to determine the source of difference.

Examination of University Students' Nomophobia, Coping with Stress, and Anger Expression Styles

\section{RESULTS}

Table 1. Statistical changes in the dimensions of Nomophobia, anger expression and coping style depending on gender

\begin{tabular}{|c|c|c|c|c|c|c|c|c|c|c|c|}
\hline \multirow[t]{2}{*}{ Gender } & \multirow[t]{2}{*}{$\mathrm{n}$} & \multicolumn{2}{|c|}{ Information } & \multicolumn{2}{|l|}{ Online } & \multicolumn{2}{|c|}{ Communication } & \multicolumn{2}{|c|}{ Comfort } & \multicolumn{2}{|c|}{ Nomophobia General } \\
\hline & & $\overline{\mathrm{x}}$ & SE & $\overline{\mathrm{x}}$ & SE & $\overline{\mathrm{x}}$ & SE & $\overline{\mathrm{x}}$ & SE & $\overline{\mathrm{x}}$ & SE \\
\hline Female & 201 & 12.44 & 2.94 & 16.34 & 3.23 & 19.55 & 3.52 & 16.26 & 3.13 & 64.60 & 6.75 \\
\hline Male & 331 & 14.39 & 2.71 & 18.46 & 2.88 & 22.30 & 3.08 & 18.01 & 2.86 & 73.16 & 5.74 \\
\hline Total & 532 & 13.65 & 2.95 & 17.66 & 3.19 & 21.26 & 3.51 & 17.35 & 3.08 & 69.92 & 7.41 \\
\hline
\end{tabular}




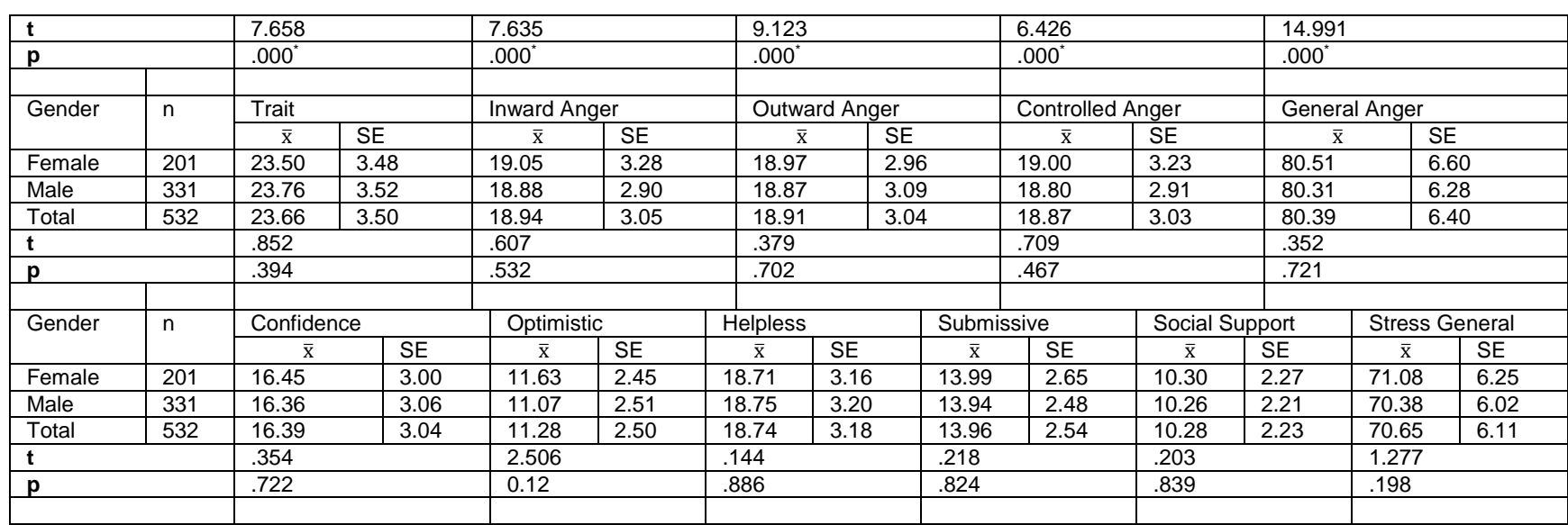

${ }^{*}=$ Significant difference between groups $(p<0.05)$; SE: Standart Error

As can be seen in Table 1; Depending on the gender factor. It was determined that the male nomophobia values were statistically higher than the female values $(p<0.05)$. On the other hand, no statistical change was observed in the dimensions of anger expression and coping with stress, depending on gender.

Table 2. Statistical changes in the dimensions of Nomophobia, Anger expression and style of coping with stress depending on age

\begin{tabular}{|c|c|c|c|c|c|c|c|c|c|c|c|c|c|}
\hline \multirow[t]{2}{*}{ Age } & \multirow[t]{2}{*}{$\mathrm{n}$} & \multicolumn{2}{|c|}{ Information } & \multicolumn{2}{|l|}{ Online } & \multicolumn{3}{|c|}{ Communication } & \multicolumn{2}{|c|}{ Comfort } & \multicolumn{3}{|c|}{ Nomophobia General } \\
\hline & & $\overline{\mathrm{x}}$ & SE & $\overline{\mathrm{x}}$ & SE & & $\overline{\overline{\mathrm{x}}}$ & SE & $\overline{\mathrm{x}}$ & SE & $\overline{\mathrm{x}}$ & & SE \\
\hline $18-22$ & 299 & 13.64 & 3.01 & 17.63 & 3.25 & 21 & & 3.60 & 17.31 & 3.03 & 69.95 & & 7.70 \\
\hline $23-27$ & 175 & 13.73 & 2.86 & 17.66 & 3.14 & 20 & & 3.49 & 17.66 & 3.12 & 69.93 & & 7.18 \\
\hline 28 and older & 58 & 13.48 & 2.93 & 17.83 & 3.04 & 21 & & 3.06 & 16.62 & 3.15 & 69.74 & & 6.58 \\
\hline \multicolumn{2}{|l|}{$\mathbf{F}$} & \multicolumn{2}{|l|}{.160} & \multicolumn{2}{|l|}{.091} & \multicolumn{3}{|c|}{1.860} & \multicolumn{2}{|l|}{2.534} & \multicolumn{3}{|l|}{.020} \\
\hline \multicolumn{2}{|l|}{$p$} & \multicolumn{2}{|l|}{.852} & \multicolumn{2}{|l|}{.913} & \multicolumn{3}{|c|}{.157} & \multicolumn{2}{|l|}{.080} & \multicolumn{3}{|l|}{.980} \\
\hline \multirow[t]{2}{*}{ Age } & $\mathrm{n}$ & \multicolumn{2}{|l|}{ Trait } & \multicolumn{2}{|c|}{ Inward Anger } & \multicolumn{3}{|c|}{ Outward Anger } & \multicolumn{2}{|c|}{ Controlled Anger } & \multicolumn{3}{|c|}{ General Anger } \\
\hline & & $\overline{\mathrm{x}}$ & SE & $\overline{\mathrm{x}}$ & SE & & $\overline{\mathrm{x}}$ & SE & $\overline{\mathrm{x}}$ & SE & $\overline{\mathrm{x}}$ & & SE \\
\hline $18-22$ & 299 & 23.68 & 3.54 & 18.88 & 2.94 & 18 & & 3.10 & 18.90 & 3.16 & 80.32 & & 6.65 \\
\hline $23-27$ & 175 & 23.65 & 3.59 & 18.98 & 3.28 & 18 & & 2.95 & 18.80 & 2.93 & 80.30 & & 6.24 \\
\hline 28 and older & 58 & 23.64 & 3.04 & 19.16 & 2.89 & 19 & & 3.04 & 18.93 & 2.68 & 80.98 & & 5.54 \\
\hline \multicolumn{2}{|l|}{$\mathbf{F}$} & \multicolumn{2}{|l|}{.004} & \multicolumn{2}{|l|}{.219} & \multicolumn{3}{|c|}{.437} & \multicolumn{2}{|l|}{.076} & \multicolumn{3}{|l|}{.283} \\
\hline \multicolumn{2}{|l|}{$p$} & .996 & & .803 & & .64 & & & .927 & & .753 & & \\
\hline Age & $\mathrm{n}$ & Confid & & Optimis & & Helple & & Submi & sive & Social & pport & Stress & General \\
\hline & & $\overline{\mathrm{x}}$ & SE & $\overline{\mathrm{x}}$ & SE & $\bar{x}$ & SE & $\overline{\mathrm{x}}$ & SE & $\overline{\mathrm{x}}$ & SE & $\overline{\mathrm{x}}$ & \begin{tabular}{l|l} 
SE \\
\end{tabular} \\
\hline $18-22$ & 299 & 16.44 & 3.10 & 11.25 & 2.52 & 18.85 & 3.25 & 13.92 & 2.68 & 10.34 & 2.26 & 70.81 & 6.19 \\
\hline $23-27$ & 175 & 16.27 & 3.09 & 11.24 & 2.41 & 18.73 & 3.04 & 14.00 & 2.40 & 10.25 & 2.27 & 70.49 & 5.96 \\
\hline 28 and older & 58 & 16.48 & 2.55 & 11.57 & 2.66 & 18.21 & 3.23 & 14.02 & 2.24 & 10.02 & 1.91 & 70.29 & 6.22 \\
\hline $\mathbf{F}$ & & .202 & & .434 & & .982 & & .068 & & .542 & & .254 & \\
\hline$p$ & & .817 & & .648 & & .375 & & .935 & & .582 & & .775 & \\
\hline
\end{tabular}

SE: Standart Error

As can be seen in Table 2, no statistical change was observed in the dimensions of Nomophobia, Anger expression and coping with stress depending on the age factor.

Table 3. Statistical changes in the dimensions of Nomophobia, Anger Expression and Coping with Stress related to the accommodation factor

\begin{tabular}{|c|c|c|c|c|c|c|c|c|c|c|c|}
\hline \multirow[t]{2}{*}{ Accommodation } & \multirow[t]{2}{*}{$\mathrm{n}$} & \multicolumn{2}{|c|}{ Information } & \multicolumn{2}{|l|}{ Online } & \multicolumn{2}{|c|}{ Communication } & \multicolumn{2}{|c|}{ Comfort } & \multicolumn{2}{|c|}{ Nomophobia General } \\
\hline & & $\overline{\mathrm{x}}$ & SE & $\overline{\mathrm{x}}$ & SE & $\overline{\mathrm{x}}$ & SE & $\overline{\mathrm{x}}$ & SE & $\overline{\mathrm{X}}$ & SE \\
\hline Family/Relatives & 288 & 13.76 & 3.09 & 17.64 & 3.15 & 21.14 & 3.63 & 17.25 & 3.12 & 69.78 & 7.38 \\
\hline Student Dormitory & 88 & 13.27 & 2.72 & 17.73 & 2.92 & 21.27 & 3.45 & 17.67 & 3.10 & 69.94 & 7.04 \\
\hline Student House & 156 & 13.68 & 2.81 & 17.66 & 3.41 & 21.48 & 3.34 & 17.35 & 3.02 & 70.17 & 7.69 \\
\hline \multicolumn{2}{|l|}{ F } & \multicolumn{2}{|l|}{.915} & \multicolumn{2}{|l|}{.024} & \multicolumn{2}{|l|}{.489} & \multicolumn{2}{|l|}{.637} & \multicolumn{2}{|l|}{.141} \\
\hline \multicolumn{2}{|l|}{$p$} & \multicolumn{2}{|l|}{.401} & \multicolumn{2}{|l|}{.976} & \multicolumn{2}{|l|}{.614} & \multicolumn{2}{|l|}{.529} & \multicolumn{2}{|l|}{.868} \\
\hline \multirow[t]{2}{*}{ Accommodation } & \multirow[t]{2}{*}{$\mathrm{n}$} & \multicolumn{2}{|l|}{ Trait } & \multicolumn{2}{|c|}{ Inward Anger } & \multicolumn{2}{|c|}{ Outward Anger } & \multicolumn{2}{|c|}{ Controlled Anger } & \multicolumn{2}{|c|}{ General Anger } \\
\hline & & $\overline{\mathrm{x}}$ & SE & $\overline{\mathrm{x}}$ & SE & $\overline{\mathrm{x}}$ & SE & $\overline{\mathrm{x}}$ & \begin{tabular}{l|l} 
SE \\
\end{tabular} & $\overline{\mathrm{x}}$ & SE \\
\hline Family/Relatives & 288 & 23.90 & 3.60 & 18.90 & 2.97 & 18.70 & 3.13 & 18.77 & 3.05 & 80.27 & 6.54 \\
\hline Student Dormitory & 88 & 23.45 & 3.24 & 18.84 & 3.24 & 19.11 & 2.89 & 18.97 & 2.76 & 80.38 & 5.69 \\
\hline Student House & 156 & 23.35 & 3.44 & 19.08 & 3.09 & 19.17 & 2.93 & 19.01 & 3.17 & 80.61 & 6.54 \\
\hline \multicolumn{2}{|l|}{$\mathbf{F}$} & \multicolumn{2}{|l|}{1.408} & \multicolumn{2}{|l|}{.224} & \multicolumn{2}{|l|}{1.485} & \multicolumn{2}{|l|}{.354} & \multicolumn{2}{|l|}{.144} \\
\hline $\mathbf{p}$ & & .246 & & .224 & & 1.485 & & .354 & & .144 & \\
\hline
\end{tabular}




\begin{tabular}{|c|c|c|c|c|c|c|c|c|c|c|c|c|c|}
\hline & & & & & & \multirow{2}{*}{\multicolumn{2}{|c|}{ Helpless }} & & & & & & \\
\hline \multirow[t]{2}{*}{ Accommodation } & \multirow[t]{2}{*}{$\mathrm{n}$} & \multicolumn{2}{|c|}{ Confidence } & \multicolumn{2}{|c|}{ Optimistic } & & & \multicolumn{2}{|c|}{ Submissive } & \multicolumn{2}{|c|}{ Social Support } & \multicolumn{2}{|c|}{ Stress General } \\
\hline & & $\overline{\mathrm{x}}$ & SE & $\overline{\mathrm{x}}$ & SE & $\overline{\mathrm{x}}$ & SE & $\overline{\mathrm{x}}$ & SE & $\overline{\mathrm{x}}$ & SE & $\overline{\mathrm{x}}$ & SE \\
\hline Family/Relatives & 288 & 16.33 & 3.07 & 11.24 & 2.47 & 18.70 & 3.02 & 13.88 & 2.59 & 10.25 & 2.19 & 70.40 & 5.68 \\
\hline Student Dormitory & 88 & 16.09 & 2.78 & 11.07 & 2.48 & 18.82 & 3.46 & 14.15 & 2.40 & 10.11 & 2.28 & 70.24 & 6.86 \\
\hline Student House & 156 & 16.69 & 3.10 & 11.47 & 2.57 & 18.76 & 3.32 & 14.01 & 2.54 & 10.42 & 2.28 & 71.33 & 6.41 \\
\hline \multicolumn{2}{|l|}{$\mathbf{F}$} & \multicolumn{2}{|l|}{1.231} & \multicolumn{2}{|l|}{.788} & \multicolumn{2}{|l|}{.049} & \multicolumn{2}{|l|}{.426} & \multicolumn{2}{|l|}{.558} & \multicolumn{2}{|l|}{1.419} \\
\hline \multicolumn{2}{|l|}{$\mathbf{p}$} & \multicolumn{2}{|l|}{.293} & \multicolumn{2}{|l|}{.455} & \multicolumn{2}{|l|}{.952} & \multicolumn{2}{|l|}{.653} & \multicolumn{2}{|l|}{.572} & \multicolumn{2}{|l|}{.243} \\
\hline
\end{tabular}

SE: Standart Error

As can be seen in Table 3, no statistical change was observed in the dimensions of Nomophobia, anger expression and coping with stress depending on the accommodation factor.

\section{DISCUSSION}

In this study, it was aimed to examine the nomophobia, coping with stress and anger expression styles of university students; While no statistical change was observed in the dimensions of coping with anger and stress depending on the gender factor, it was determined that the mean value of males was statistically higher than that of females in all Nomophobia dimensions (Table $1 ; p<0.05$ ).

It is possible to come across many studies in the literature on whether anger expression styles vary depending on gender. It is possible to come across studies that do not report any change $\mathrm{e}^{25,26}$ as well as studies reporting gender-related changes ${ }^{27,28}$ When the feel of anger can be controlled, it can be reflected positively on emotions and behaviors by individuals. The findings of our research are similar to the studies of Demir et al. ${ }^{25}$ and Sağlam ${ }^{26}$. In addition to social and cultural changes, it is thought that the changes in the social position, status and roles of female and male in accordance with today's life have affected this result.

In addition to the studies that reported changes in the dimensions of coping with stress depending on the gender factor 29,30,31,32,33,34,35,36, there are fewer studies that did not report any difference ${ }^{37,38}$. Findings of our study is similar to the results of Karakaş and Koç ${ }^{37}$, Tekin ${ }^{38}$ In today's world, depending on the social and cultural structure, it is very difficult for male and female to adopt a profile that is suitable for the previously envisaged status and roles. Sharing these status and roles is almost a necessity. Male and female can carry out many different tasks that have become their own responsibilities without question.

Whether it is a woman or a man, stress must be kept at a controllable level in order to get out of a structure that suppresses behaviors and prevents positive emotions and behaviors.

It is possible to come across studies in different fields and sizes, in which nomophobia is reported to change depending on gender ${ }^{39,40,41}$ and no change due to gender $42,43,44,45,46$. Taştan ${ }^{47}$ reported that the nomophobia level of male university students was higher than that of female university students, and this change was statistically significant. In this respect, Taştan ${ }^{47}$ 's study coincides with our research findings. There are many studies in the literature that females have a higher nomophobia value than males ${ }^{41,48,49,50,51}$ Nomophobia is an addiction and like all addictions, it can cause physical and mental problems in individuals. In the social structure, it is seen that females are more dependent on home life and housework. Technological and cultural changes make males and females close to each other and open to technological addiction.

No statistical change was found in the values of anger, nomophobia and coping with stress depending on the age factor of the students (Table 2).

Sağlam ${ }^{26}$ found that the levels of trait anger, anger outwards, anger inwards, anger-control did not differ significantly in university students according to the age variable. Demir et al. ${ }^{25}$ and Cengiz et al. ${ }^{52}$ do not report a statistical change in the anger expression styles of university students depending on the age factor. In this respect, the findings of our research are similar to these studies in the literature.

Examination of University Students' Nomophobia, Coping with Stress, and Anger Expression Styles

Şen et al. ${ }^{53}$ did not report a significant relationship between age ranges and styles of coping with stress. Eraslan ${ }^{33}$ reported that there was no statistically significant difference between the scores of coping with stress according to age groups of university students studying in sports departments. Our research findings are similar in this aspect with the study findings of Şen et al. ${ }^{53}$ and Eraslan ${ }^{34}$. It is also possible to come across studies reporting significant changes between stress and age 54,55 . Ergin et al. ${ }^{56}$ found that, styles of coping with stress are used more as age increases. Aşcı et al. ${ }^{57}$ found that university students' methods of coping with stress did not differ in terms of age variables. In the literature, it is possible to find different findings and results regarding the coping styles of age groups with stress. In addition to different living spaces and problems, socio-cultural structure is thought to be the reason for this situation.

SecurEnvoy ${ }^{39}$ stated that $77 \%$ of young people between the ages of 18-24 stated that the thought of losing their mobile phones caused them anxiety and they felt fear in this sense. There are many studies in the literature suggesting that nomophobia does not show a statistical change depending on the age factor ${ }^{43,58,59,60}$. These studies are important in that they are similar to the findings of our study. Studies reporting a change between nomophobia and age ${ }^{24,61,62}$ are also substantial. The reason for this difference can be explained by the different scope and dimensions of the studies.

No statistical change was found in the values of anger, nomophobia and coping with stress depending on the accommodation factor of the students (Table 3). Elkin and Karadağ $\left.\right|^{27}$ do not report a statistical change in anger expression styles depending on the factors of the place where students spent their childhood and where they live. Yöndem and Bıçak ${ }^{63}$ do not report any change in the anger expression styles of students depending on their form of 
accommodation. Our research's findings are similar to the studies of Elkin and Karadağlı ${ }^{27}$ and Yöndem and Bıçak ${ }^{63}$. Family life is of great importance in protecting and improving the quality of life of individuals, as well as facilitating the adaptation of individuals and families to current and changing conditions. It is seen that the majority of university students live with their families and relatives, and those who stay in dormitories and student houses do not break their ties with their families with the innovations brought by technology. Therefore, this current situation can be seen as the reason why no change was observed depending on the accommodation factor.

Studies that did not report any difference ${ }^{57,64,65,72}$. Hancıoğlu66, on the other hand, concluded that there is a difference between the place of residence of the students and their stress levels. Reports that the most stressful group consists of those who stay at home with a few friends, followed by groups living with the family, living in the dormitory, and living alone at home, respectively. University life is too vivid to support the habit of staying in one place, and young people may need shelter just to sleep. Studies in the literature that do not report a change in coping with stress due to the accommodation factor ${ }^{64,65}$ support our research findings. The important factor here is how young people approach their problems and look for a solution, rather than the place where they live.

Deniz ${ }^{67}$ reports that there is no significant relationship between problematic phone use and living with family. Balcı and Gülnar ${ }^{68}$ report that the form of accommodation of university students do not cause a significant change in their internet addiction levels. Acat ${ }^{69}$ reports that students staying in dormitories or hostels or with their families do not have a significant effect on their internet addiction levels. Bağış ${ }^{70}$ states that there is no significant difference in internet addiction levels of university students according to where they live and with whom they live. In this respect, the findings of our study show similarities with the studies in the literature. It is also possible to come across some studies reporting a statistical change between nomophobia and accommodation factor. Kartal ${ }^{71}$ in the study applied to the students of the faculty of health sciences; reported that those who live with their families are more nomophobic than those who live in dormitories. No matter where university youth reside, they can establish a virtual world for themselves with the innovations brought by technology 73 . Therefore, these research findings can be seen as the reason why individuals do not show a nomophobic change depending on the accommodation factor.

Depending on today's socio-cultural structure, the social roles and status that society imposes on female and male have made female and male student profiles indistinguishable from each other, depending on technological developments and innovations. This situation can be seen as the reason for the similarity in the values of anger expression and coping with stress observed in our study. The source of the changes in high nomophobia values of males can be considered as being more dependent on smartphones than females. In addition to technological developments and innovations, the Covid-19 pandemic has paved the way for digital addictions as well as causing negative emotions and behaviors. University students have to find a solution to this new problem in addition to many different problems. Studies on nomophobia, coping with stress and anger expression styles in university youth are very limited. It is thought that our research will shed light on studies to be conducted in different scopes and dimensions.

\section{CONCLUSION}

The result of this study while no statistical change was observed in the dimensions of coping with anger and stress depending on the gender factor, it was determined that the mean value of males was statistically higher than that of females in all nomophobia dimensions. There was no statistical change in the values of anger, nomophobia and coping with stress depending on the age and accommodation factors of the students. Today, the fact that females and males are closer to each other in respect of social status and social roles can be seen as the reason for the similarity in the values of anger expression and coping with stress. Results related to high nomophobia values of males can be evaluated as they are more addicted to smartphones than females. Studies on nomophobia, coping with stress and anger expression styles in university youth are very limited. It is thought that our research will shed light on studies to be conducted in different scopes and dimensions.

\section{REFERENCES}

1. WHO. (2020). Adolescent and reproductive health and rights. Last access date: 15.01.2020 http://www.icc.org.tr/icerik.php? id=12\&kid

$=3$.

2. Bayram N, Bilgel $\mathrm{N}$. The Prevalence and SocioDemographic Correlations of Depression, Anxiety and Stress among a Group of University Students. Social Psychiatry and Psychiatric Epidemiology, 2008; 43: 667-672. http://dx.doi.org/10.1007/s00127-008-0345-x

3. Çam Çelikel F, Erkorkmaz Ü. Factors associated with depressive symptoms and hopelessness levels in university students. Neuropsychiatry Archive, 2008; 45: 122-129.

4. Hollenhorst PS. What Do We Know About Anger Management Programs in Corrections, Federal Probation, USA:, 1998; 62 (2): 52-64.

5. Kısaç İ. Trait anger expression levels of university students according to some variables (Doctoral Thesis). Hacettepe University, Institute of Social Sciences, 1997; Ankara.

6. Greenberg SF. Stress and the teaching profession, Paul H. Brookes Publishing Co., Inc., London, 1984.

7. Yıldırım C, Correia AP. Exploring the dimensions of nomophobia: Development and validation of a self-reported questionnaire. Computers in Human Behavior, 2015; 49: 130-137. https://doi.org/10.1016/j.chb.2015.02.059

8. King ALS, Valença AM, Silva ACO, Baczynski T, Carvalho MR, Nardi AE. Nomophobia: Dependency on virtual environments or social phobia? Computers in Human Behavior, $2013 ; \quad 29 \quad$ (1): $140-144$. https://doi.org/10.1016/j.chb.2012.07.025

9. Kuss DJ, Griffiths MD. Addiction to social networks on the Internet: a literature review of empirical research. International Journal of Environmental and Public Health, 2011; 8: 3528-3552. https://doi.org/10.3390/ijerph8093528

10. Bragazzi NL, Del Puente G. A proposal for including nomophobia in the new DSM-V. Psychol Res Behav Manag, 2014; 7: 155-160. https://doi.org/10.2147/PRBM.S41386

11. Karatay S. Mobile social media applications in the context of hyperconnectivity: A research on nomofobia and fomo 
disasters (Master Thesis) Istanbul University, Institute of Social Sciences, 2018; Istanbul.

12. Özgür Güler E, Veysikarani D. A research on nomophobia: example of university students. Journal of Beykoz Academy, 2019; $7(1): 75-88$ https://doi.org/10.14514/BYK.m.26515393.2019.7/1.75-88

13. Gününç $S$, Kayri $M$. The profile of internet dependency in turkey and development of internet addiction scale: study of validity \& reliability. Hacettepe University, Journal of the Faculty of Education, 2010; 39: 220-232.

14. Rosenberg DE, Norman GJ, Wagner N, Patrick K, Calfas KJ, Sallis JF. Reliability and validity of the Sedentary Behavior Questionnaire (SBQ) for adults. Journal of Physical Activity and Health, 2010; 7 (6): 697-705. https://doi.org/10.1123/jpah.7.6.697

15. Hazar Z, Demir GT, Namlı S, Türkeli A. Investigation of the relationship between digital game addiction and physical activity levels of secondary school students. Journal of Physical Education and Sport Sciences, 2017; 11 (3): 319332.

16. Adnan M, Gezgin DM. A Modern Phobia: Prevalence of Nomophobia among College Students. Ankara University, Journal of Faculty of Educational Sciences, 2016; 49 (1): 141-158. https://doi.org/10.1501/Egifak_0000001378

17. Chen L, Yan Z, Tang W, Yang F, Xie X, He J. Mobile phone addiction levels and negative emotions among Chinese young adults: the mediating role of interpersonal problems. Computers in Human behavior, 2016; 55: 856-866. https://doi.org/10.1016/j.chb.2015.10.030

18. Lee H, Ahn H, Choi S, Choi W. The SAMS: Smartphone addiction management system and verification. Journal of Medical Systems, 2014; 38 (1): 1-12. https://doi.org/10.1007/s10916-013-0001-1

19. Spielberger CD, Jacobs G, Russel FS, Crane RS. Assessment of anger: the state-trait anger scale. In: Butcher JN, Spielberger CD (ed.), Advances in Personality Assessment, 2. Hillsdale, NJ/ABD: Lawrence Erlbaum and Associates; 1983; 159-60.

20. Özer AK. Preliminary study of trait anger and anger expression style (anger style) scales. Turkish Journal of Psychology, 1994; 9 (31): 26-35.

21. Folkman S, Lazarus RS. An analysis of coping in a middleaged community sample. Journal of Health and Social Behaviour, $1980 ; \quad 21$ 219-239. https://doi.org/10.2307/2136617

22. Şahin, $\mathrm{NH}$, Durak $\mathrm{A}$. The scale of coping styles with stress: Adaptation for university students. Turkish Journal of Psychology, 1995; 10 (34): 56-73.

23. Yıldırım C, Sumuer E, Adnan M, Yıldırım S. A growing fear Prevalence of nomophobia among Turkish college students. Information Development, 2016; 32 (5): 1322- 1331. https://doi.org/10.1177/0266666915599025

24. Erdem H, Türen $U$, Kalkın $G$. No mobile phone phobia (nomophobia) prevalence: Samples of undergraduate students and public employees from Turkey. Journal of Information Technology, 2017; 10 (1): 1-12.

25. Demir H, Sezan T, Demirel H, Yalçın YG, Altın M. Anger expression styles of athletes. Mehmet Akif Ersoy University, Journal of Social Sciences Institute, 2017; 9 (19): 408-414. https://doi.org/10.20875/makusobed.295361

26. Sağlam E. The relationship between trait anger and anger styles levels and empathy and forgiveness levels in university students (Master Thesis). Gazi University, Institute of Educational Sciences, 2020; Ankara.

27. Elkin N, Karadağlı F. Anger Expression and Related Factors in University Students. Anatolian Clinic the Journal of Medical Sciences, 2016; $21 \quad$ (1): 64-71. https://doi.org/10.21673/anadoluklin.180680

28. Bostancı N, Çoban S, Tekin Z, Özen A. Anger Expression According to Sexuality of University Students. Kriz Journal,
2006; 14 (3): 9-18. https://doi.org/10.1501/Kriz 0000000252

29. Özkubat S, Çakmak A. Investigation of university students' coping with the stress practices. Academic View Journal, 2017; 64: 286-295.

30. Altundağ G. Examining attachment styles, coping styles with stress and perceived stress level among university students (Master Thesis). Haliç University, Institute of Social Sciences, 2011; Istanbul.

31. Yurtsever $\mathrm{H}$. The effect of personality characteristics on stress level and coping ways with stress: A research on university students (Master Thesis). Dokuz Eylul University, Institute of Social Sciences, 2009; Izmir.

32. Day AL, Livingstone HA. Gender differences in perceptions of stressors and utilization of social pupport among university students. Canadian Journal of Behavioral Science, 2003; 35 (2): 73-83. https://doi.org/10.1037/h0087190

33. Doğru N. An investigation of psychological well-being, stress, coping and social support of university students (Doctoral Thesis). Ankara University, Institute of Educational Sciences, 2018; Ankara.

34. Erarslan M. Investigation personality aspects and coping style to stress of students taking education at sport departments in terms of some variables. Mehmet Akif Ersoy University, Journal of Social Sciences Institute, 2015; 7 (12): 65-82. Examination of University Students' Nomophobia, Coping with Stress, and Anger Expression Styles

35. Keleş D. Relationship between university students' eating attitudes and dissociative experiences and sruggle with stress (Master Thesis). Üsküdar University, Institute of Social Sciences, 2018; Istanbul.

36. Yamaç Ö. The relationship the styles of the defeating the stress with the social support which the university students percepted (Master Thesis). Selçuk University, Institute of Social Sciences, 2009; Konya.

37. Karakaş AC, Koç $M$. The relationship between religious coping and coping with stress methods: An analysis from various of variable. Journal of the Human and Social Sciences Researches, 2014; 3 (3): 610-631. https://doi.org/10.15869/itobiad.88954

38. Tekin Ö. A research on the stress coping strategies of primary school principals in terms of some variables (Master Thesis). Ege University, Institute of Social Sciences, 2009; Izmir.

39. SecurEnvoy. $66 \%$ of The Population Suffer from Nomophobia The Fear of Being without Their Phone, https://www.securenvoy.com/blog/2012/02/16/66-ofthepopulation-suffer-from-nomophobia-the-fear-of-beingwithout-their-phone. 2012.

40. Roberts JA, Yaya LH, Manolis C. The invisible addiction: cellphone activities and addiction among male and female college students. Journal of behavioral addictions, 2014; 3 (4): 254-265. https://doi.org/10.1556/jba.3.2014.015

41. Burucuoğlu M. A research on the nomophobia levels of vocational school students. Karabuk University, Journal of Social Sciences Institute, 2017; 7 (2): 482-489.

42. Yaman Z, Kavuncu B. The effect of university students' fear of abduction of social developments and social networking purpose on nomophobia level. Journal of Social Sciences Studies, 2019; 14 (2): 555-570.

43. Öz H. Investigation of university students' nomophobia levels between personality types (Master Thesis). Istanbul Aydın University, Institute of Social Sciences, 2018; Istanbul.

44. Jood TE. Missing the present for the unkown: The relationship between fear of missing out (fomo) and life satisfaction (Master Thesis). University of South Africa, 2017.

45. Polat R. Nomophobia as digital disease. e-Journal of New Media, 2017; 2 (1): 164-172. https://doi.org/ 10.17932/IAU.EJNM.25480200.2017.1/2.164-172

46. Yoğurtçu DD. The relationship between five factor 
personality traits and nomophobia levels among university students (Master Thesis). Yeditepe University, Institute of Educational Sciences, 2018; Istanbul.

47. Taştan S. Investigation of internet addiction and nomophobia levels in university students doing sports and non-exercising (Master Thesis). Süleyman Demirel University, Institute of Health Sciences, 2020; Isparta.

48. Tavolacci MP, Meyrignac G, Richard L, Dechelotte P, Ladner J. Problematic use of mobile phone and nomophobia among French college students. The European Journal of Public Health, 2015; $25 \quad$ (3): 172-088. https://doi.org/10.1093/eurpub/ckv172.088

49. Uysal Ş, Özen H, Madenoğlu C. Social phobia in higher education: the influence of nomophobia on social phobia. The Global e-learning Journal, 2016; 5 (2): 1-8.

50. Büyükçolpan $\mathrm{H}$. Nomophobia, attachment styles, depression and perceived social support among university students (Master Thesis). Hacettepe University, Institute of Educational Sciences, 2019; Ankara.

51. Akman E. The effect of the nomophobia on academic success: An evaluation on the political science and public administration students of suleyman demirel university. International Journal of Euroasian Researches, 2019; 7 (16): 256-275. https://doi.org/10.33692/avrasyad.543756

52. Cengiz $R$, Koçak $F$, Sunay $H$. Investigation of the level of anger and impulsive behavior of the high school of physical education and sports students. Spormetre, 2018; 16 (1): 2938. https://doi.org/10.1501/Sporm_0000000339

53. Şen H, Toygar $M$, Türker $T$, Ince $N$, Tuğcu H, Keskin H. Evaluation of stress coping techniques of a group of physicians. TAF Prev Med Bull, 2012; 11: 211-8.

54. Tavlı F, Ünsal G. Assesment of sources of stress among factory employees and their attitudes to cope with stress. Journal of Academic Resarch in Nursing, 2016; 2 (1): 9-15. https://doi.org/10.5222/jaren.2016.009

55. Çavdarlı Ş. Relationship between high school athletes' task and ego orientations and coping with stress strategies in sport (Master Thesis). Mersin University, Institute of Educational Sciences, 2013; Mersin.

56. Ergin A, Uzun SU, Bozkurt Al. The methods of coping with the stress among medical faculty students and the relationship between sociodemographic characteristics and these methods. Firat Med J, 2014; 19 (1): 31-37.

57. Aşcı Ö, Hazar G, Kılıç E, Korkmaz A. Determining the reasons of stress and the ways of coping with stress in university students. Uşak University, Journal of Social Sciences, 2015; 8 (4): 213-232.

58. Kuzu M. Examining the relationship between the nomophobic profiles of university students and participation in recreational activities with different variables (Master Thesis). Onsekiz Mart University, Institute of Health Sciences, 2020; Çanakkale.

59. Apak E, Yaman OM. The prevalence of nomophobia among university students and nomophobia's relationship with social phobia: The Case of Bingöl University Addicta: The Turkish Journal on Addictions, 2019; 6 (3): 611-629. http://dx.doi.org/10.15805/addicta.2019.6.3.0078
60. Ak NY, Yıldırım S. Nomophobia among undergraduate students: The case of a Turkish state university. International Journal on New Trends in Education and Their Implications, 2018; 9 (4): 11-20.

61. Sezer B, Atılgan SBÇ. The dark side of smartphone usage (Nomophobia): Do we need to worry about it?. World of Medical Education, 2019; 18 (54): 30-43. https://doi.org/10.25282/ted.513988

62. Gezgin DM, Sumuer E, Arslan O, Yıldırım S. Nomophobia Prevalence among Pre-service Teachers: A case of Trakya University. Trakya University Trakya Journal of Education, 2017; 7 (1): 86-95.

63. Yöndem ZD, Bıçak B. Anger and anger styles of the teacher candidates. International Journal of Human Sciences, 2008; 5 (2): 1-15.

64. Özdemir İ. Comparing percieved social support, coping strategies, anxiety levels and psychological symptoms of university students living with their parents and away from their parents (Master Thesis). Hacettepe University, Institute of Social Sciences, 2013; Ankara.

65. Fırat N. An examination of social support level and stress coping strategies of students staying at home or in dormitory (Master Thesis). Gaziosmanpaşa University Institute of Educational Sciences, 2015; Tokat.

66. Hancıoğlu Y. The investigation of relationship between perceived stress level of university students and styles of coping with stress. Journal of Management and Economics $\begin{array}{llll}\text { Research, } 2017 ; & 15 & \text { (1): } 130-149 .\end{array}$ https://doi.org/10.11611/yead.270449

67. Deniz S. Relation between problematic mobile phone use and social anxiety and shyness level (Master Thesis). Istanbul Arel University, Institute of Social Sciences, 2014; Istanbul.

68. Balcı Ş, Gülnar B. Internet addiction among university students and the profile of internet addicts. Selçuk Communications, 2009; 6 (1): 5-22.

69. Acat B. The relationship between religiosity, values, internet addiction and life satisfaction among adolescents (Master Thesis). Marmara University, Institute of Social Sciences, 2019; Istanbul.

70. Bağış A. Status of internet addiction and evaluation of its effects on daytime sleepiness among medical students in Trakya University (Specialist Thesis). Trakya University, Faculty of Medicine, 2016; Edirne.

71. Kartal YA. The investigation of the relationship between midwifery students 'fear of lack of mobile phone and the perception of social support. Celal Bayar University Journal of Institute of Health Sciences, 2019; 6(4): 308-312. https://doi.org/10.34087/cbusbed.600130

72. Ilkim, M., Tanir, H., \& Özdemir, M. Socialization Effect of Physical Activity in Students Who Need Special Education. Asian Journal of Education and Training, 2018; 4(2), 128131.

73. Salehian MH, Gursoy R, Aftabi GR, Taghizadeh M. Comparison of depression between university athletes and non-athletes European Journal of Experimental Biology 2 (4), 1008-1011 